\title{
Editorial to the topical collection in Environmental Earth Sciences "Stone in the architectural heritage: from quarry to monuments-environment, exploitation, properties and durability"
}

\author{
Siegfried Siegesmund ${ }^{1} \cdot$ Luís Sousa $^{2,3} \cdot$ Rubén Alfonso López-Doncel $^{4}$
}

Published online: 29 October 2018

(c) Springer-Verlag GmbH Germany, part of Springer Nature 2018

When we look at the architectural beauty of a building or monument erected with natural building stones, we normally never think of all the effort that was needed for the extraction of the building stones from the quarry, the transportation to a workshop for cutting, and the polishing or carving by expert hands. The result of all these processes is a monumental task that represents the idiosyncrasies and identity of different peoples and cultures. These structures bear witness to all their efforts.

The description of the natural building stones, from their origin to their mineralogical composition is the domain of the geologist. However, when it comes to stones that were used in the construction of the architectural heritage, a multidisciplinary staff of specialists from diverse branches are required, such as architects, restorers, chemists, engineers and even anthropologists. These specialists are also necessary when investigating the exploitation, environment, properties and the durability of natural building stones.

This special issue with 39 scientific papers includes 133 researchers from 83 different institutions and departments that cover topics from three continents. These papers reflect a multidisciplinary work with topics that include the most diverse aspects of the stones from the quarry to the monuments.

Nowadays aesthetic characteristics is the main factor considered during the selection of the natural stones by

Siegfried Siegesmund

ssieges@gwdg.de

1 Department Structural Geology and Geodynamics, Geowissenschaftliches Zentrum der Universität Göttingen, Göttingen, Germany

2 Geology Department, University of Trás-os-Montes e Alto Douro, Vila Real, Portugal

3 CEMMPRE Research Centre, Coimbra, Portugal

4 Instituto de Geología, Universidad Autónoma de San Luis Potosí, San Luis Potosí, Mexico the users. However, other properties and factors control the quarrying. Some are related to the material itself like the physical-mechanical properties, others are extrinsic to the stone such as the market demand or environmental constraints on the exploitation areas. During the exploration for natural building stones, all the factors should be carefully studied in order to achieve a correct evaluation in the three dimensional stone cycle: exploitation, transformation and application.

The delimitation of potential areas for ornamental stone production uses methodologies based on the main geological criteria. These are the homogeneity criterion, which is related to the textural and chromatic homogeneity of the potentially productive lithologic units, and the dimension criterion, referring to the thickness of the productive unit (Carvalho and Lisboa 2018). However, in some cases, like the marbles, the textural and colour heterogeneity enhances the visual quality of the material (Menningen et al. 2018a). Regardless of the rock type the fracturing plays an important role in the definition of the available areas (Santos et al. 2018), since in high fractured massifs is more difficult extracting commercial blocks.

Physical-mechanical properties are the consequence of several factors, like mineralogy, texture, cracking, among others, and are important to define the possible application as well the behaviour face to weathering. The importance of each factor varies from stone to stone, not only according to the mineralogy but also within the geological background. In granitic stones the petrographic features have an influence on the strength (Vazquez et al. 2018) and the thermal behaviour (Siegesmund et al. 2018). In tuff stones the chemical composition, the textural and fabrics homogeneity and the degree of crystallinity play an important role in the thermal expansion (López-Doncel et al. 2018). Moreover, the presence of swellable clay minerals as well intracrystalline swelling causes hydric expansion and is an important factor for the weathering behavior and deterioration (Pötzl et al. 
2018a). Marbles usually shows a lattice and shape preferred orientation, consequently the thermal dilatation exhibits a strong directional dependence and irreversible length change after repeated heating cycles under dry and wet conditions (Menningen et al. 2018a). Sandstones can show expansion and shrinkage during imbibition of fluids depending on the surface tension of the imbibing fluid, the degree of saturation, the rigidity and the effective pore radius (Möller et al. 2018).

The weathering evolution of stones after centuries of exposure, when the decay is faster than expected, is studied by considering the rock properties and the environmental conditions as well by the implementation of ageing tests. The potential weathering of the stones is mainly governed by the porosity and pore properties that control water transport and salt and ice crystallization (Benavente et al. 2018; Carvalho et al. 2018; Sousa et al. 2018; Pötzl et al. 2018b), often in combination with site-specific conditions (Stück et al. 2018). The scaling in magmatic rocks is related to clay phases and phyllosilicates, which cause the swelling and during humidification and drying cycles (Tiennot et al. 2018). Limestone with stylolites show decay forms as result of the unequal thermal expansion of the stone material and the filling constituents of the stylolite and/or the hydric expansion of the clay content (Aly et al. 2018). Pollutants in the atmosphere are prone to cause aesthetic alterations, such as color changes due to salt precipitation, oxidation of metallic compounds, and the deposition of particulate matter (Auras et al. 2018; Gibeaux et al. 2018). Despite the decreasing trends in air pollution, large amounts of air pollution related minerals and organic pollutants are still found in the black weathering crusts of European carbonate buildings (Farkas et al. 2018). The major salt types in samples of efflorescence on buildings and monuments are gypsum, magnesium sulphates and sodium sulphates, indicating the dominating role of hydraulic binders and the long-term influence of air pollution (Siedel 2018). Microorganisms are key players in stone surface colonization and penetration (Kirchhoff et al. 2018), and causes esthetic damages and disintegrates the rock surfaces through biomineralization and the formation of oxalate crystals (González-Gómez et al. 2018). Microbial activity has the potential to modify artifacts from historic mining areas, due to metal mobilization by leaching, and remediation measures should be considered (Amin et al. 2018). In some special cases, the formation of carbonate crusts is not related to the stone itself but from water runoff with high contents of carbonate ions (Vereshchagin et al. 2018).

Interventions on building monuments is often problematic because it is hard to find samples of material for study. The non-destructive techniques are often the only available option to obtain decay maps (İnce et al. 2018; Menningen et al. 2018b; Pirskawetz 2018) or the mechanical properties of the ancient construction materials (Orenday-Tapia et al. 2008). The rehabilitation of the architectural heritage must be done according to petrophysical criteria, instead of using exclusively an aesthetic valuation (Martínez-Martínez et al. 2018). Whenever possible the original material should be used (Lecuit et al. 2018), and should be located near the architectural complexes since the location is the key factor for the stone selection rather than the specific properties of the stone (Lange et al. 2018; Columbu 2018). However, the replacement of the original material must be considered when the micro-environmental conditions related with architectural constraints cause specific decay problems (Catarino et al. 2018).

The execution of any conservation/prevention process should be preceded by a correct evaluation of the cause of decay. Lichen colonies can successfully be removed by lowenergy laser treatment in basalts with a high content of $\mathrm{Fe}$ and $\mathrm{Ti}$ oxides (Gemeda et al. 2018). The use of consolidants improves the drainage of the water during the drying process and increases the durability of the materials (Molina et al. 2018). The use of a treatment based on the formation of hydroxyapatite do not cause excessive pore occlusion and stiffening, and therefore enhances marble durability to thermal cycles and bowing (Sassoni et al. 2018). Weathering crusts can have significant differences in hydric and thermal expansion in relation to the stone and the conservation treatment should promote the reduction of this heterogeneity (Wedekind et al. 2018). 3D mapping of sculptures leads to a more accurate evaluation of the damage phenomena, therefore better conservation measures can be planned (Pfeuffer et al. 2018), which includes winter shelters designed and adapted with respect to the material properties (Franzen 2018).

The monuments are an expression of human activity, which evolves together with the historical land use originating cultural landscapes (Hoppert et al. 2018). This special issue intends to be an aid in helping to preserve the architectural heritage in urban areas, where pollution and the overuse of these monuments can be problematic. Furthermore, these studies can provide needed information for rural regions, where the loss of population and land-use changes may lead to a decline of the historical cultural landscape.

Rather than having a systematization of all problems related to stones in the Architectural Heritage, this issue presents some special case studies. We are aware that many important topics are still missing in this broad thematic collection. This volume is a overview of the immense work still to be done in this fascinating field of research. 


\section{References}

Aly N, Wangler T, Török Á (2018) The effect of stylolites on the deterioration of limestone: possible mechanisms of damage evolution. Environ Earth Sci 77:565. https://doi.org/10.1007/ s12665-018-7746-2

Amin N, Schneider D, Hoppert M (2018) Bioleaching potential of bacterial communities in historic mine waste areas. Environ Earth Sci 77:542. https://doi.org/10.1007/s12665-018-7714-x

Auras M, Bundschuh P, Eichhorn J et al (2018) Salt deposition and soiling of stone facades by traffic-induced immissions. Environ Earth Sci 77:323. https://doi.org/10.1007/s12665-018-7502-7

Benavente D, Martinez-Martinez J, Cueto N et al (2018) Impact of salt and frost weathering on the physical and durability properties of travertines and carbonate tufas used as building material. Environ Earth Sci 77:147. https://doi.org/10.1007/s1266 5-018-7339-0

Carvalho JMF, Lisboa JV (2018) Ornamental stone potential areas for land use planning: a case study in a limestone massif from Portugal. Environ Earth Sci 77:206. https://doi.org/10.1007/ s12665-018-7382-x

Carvalho C, Silva Z, Simão J (2018) Evaluation of Portuguese limestones' susceptibility to salt mist through laboratory testing. Environ Earth Sci 77:523. https://doi.org/10.1007/s12665-018-7670-5

Catarino L, Gil FPSC, Quinta-Ferreira M et al (2018) Characterization and rehabilitation of the "Porta Férrea" stone materials, University of Coimbra, Portuga. Environ Earth Sci 77:416. https ://doi.org/10.1007/s12665-018-7587-z

Columbu S (2018) Petrographic and geochemical investigations on the volcanic rocks used in the Punic-Roman archaeological site of Nora (Sardinia, Italy). Environ Earth Sci 77:577. https://doi. org/10.1007/s12665-018-7744-4

Farkas O, Siegesmund S, Licha T et al (2018) Geochemical and mineralogical composition of black weathering crusts on limestones from seven different European countries. Environ Earth Sci 77:211. https://doi.org/10.1007/s12665-018-7384-8

Franzen C (2018) Sheltering of stone art. Environ Earth Sci 77:299. https://doi.org/10.1007/s12665-018-7478-3

Gemeda BT, Lahoz R, Caldeira AT et al (2018) Efficacy of laser cleaning in the removal of biological patina on the volcanic scoria of the rock-hewn churches of Lalibela, Ethiopia. Environ Earth Sci 77:36. https://doi.org/10.1007/s12665-017-7223-3

Gibeaux S, Thomachot-Schneider C, Eyssautier-Chuine S et al (2018) Simulation of acid weathering on natural and artificial building stones according to the current atmospheric $\mathrm{SO}_{2} / \mathrm{NO}_{x}$ rate. Environ Earth Sci 77:327. https://doi.org/10.1007/s12665-018-7467-6

González-Gómez WS, Quintana P, Gómez-Cornelio S et al (2018) Calcium oxalates in biofilms on limestone walls of Maya buildings in Chichén Itzá. Mexico Environ Earth Sci 77:230. https:// doi.org/10.1007/s12665-018-7406-6

Hoppert M, Bahn B, Bergmeier E et al (2018) The Saale-Unstrut cultural landscape corridor. Environ Earth Sci 77:58. https:// doi.org/10.1007/s12665-017-7222-4

İnce İ, Bozdağ A, Tosunlar MB et al (2018) Determination of deterioration of the main facade of the Ferit Paşa Cistern by nondestructive techniques (Konya, Turkey). Environ Earth Sci 77:420. https://doi.org/10.1007/s12665-018-7595-z

Kirchhoff N, Hoppert M, Hallmann C (2018) Algal and fungal diversity on various dimension stone substrata in the Saale/Unstrut region. Environ Earth Sci 77:609. https://doi.org/10.1007/s1266 5-018-7791-x

Lange JM, Kaden M, Janetschke N (2018) Petrographic investigations in cemeteries in Dresden: a scientific view on the tombstone inventory including historic and cultural aspects. Environ Earth Sci 77:620. https://doi.org/10.1007/s12665-018-7789-4
Lecuit MX, Fronteau G, Boulvain F et al (2018) Geochemical characterization of "Lorraine limestones" from the Saint-Paul Cathedral of Liège (Belgium): assumptions for the true provenance of the building stones. Environ Earth Sci 77:361. https ://doi.org/10.1007/s12665-018-7554-8

López-Doncel R, Wedekind W, Aguillón-Robles A et al (2018) Thermal expansion on volcanic tuff rocks used as building stones: examples from Mexico. Environ Earth Sci 77:338. https://doi. org/10.1007/s12665-018-7533-0

Martínez-Martínez J, Pola A, García-Sánchez L et al (2018) Building stones used in the architectural heritage of Morelia (México): quarries location, rock durability and stone compatibility in the monument. Environ Earth Sci 77:167. https://doi.org/10.1007/ s12665-018-7340-7

Menningen J, Siegesmund S, Tweeton D et al (2018a) Ultrasonic tomography: non-destructive evaluation of the weathering state on a marble obelisk, considering the effects of structural properties. Environ Earth Sci 77:601. https://doi.org/10.1007/s1266 5-018-7776-9

Menningen J, Siegesmund S, Lopes L et al (2018b) The Estremoz marbles: an updated summary on the geological, mineralogical and rock physical characteristics. Environ Earth Sci 77:191. https://doi.org/10.1007/s12665-018-7328-3

Molina E, Fiol C, Cultrone G (2018) Assessment of the efficacy of ethyl silicate and dibasic ammonium phosphate consolidants in improving the durability of two building sandstones from Andalusia (Spain). Environ Earth Sci 77:302. https://doi.org/10.1007/ s12665-018-7491-6

Möller M, Buntebarth G, Weller A (2018) Expansion and shrinkage of sandstones during spontaneous imbibition of fluids. Environ Earth Sci 77:571. https://doi.org/10.1007/s12665-018-7753-3

Orenday-Tapia EE, Pacheco-Martínez J, Padilla-Ceniceros R et al (2018) In situ and nondestructive characterization of mechanical properties of heritage stone masonry. Environ Earth Sci 77:286. https://doi.org/10.1007/s12665-018-7473-8

Pfeuffer C, Rahrig M, Snethlage R et al (2018) 3D mapping as a tool for the planning of preservation measures on sculptures made of natural stone. Environ Earth Sci 77:312. https://doi. org/10.1007/s12665-018-7479-2

Pirskawetz SM (2018) The burned shield-bearers: a detective story. Environ Earth Sci 77:130. https://doi.org/10.1007/s1266 5-018-7267-Z

Pötzl C, Dohrmann R, Siegesmund S (2018a) Clay swelling mechanism in tuff stones: an example of the Hilbersdorf Tuff from Chemnitz, Germany. Environ Earth Sci 77:188. https://doi. org/10.1007/s12665-018-7345-2

Pötzl C, Siegesmund S, Dohrmann R et al (2018b) Deterioration of volcanic tuff rocks from Armenia: constraints on salt crystallization and hydric expansion. Environ Earth Sci 77:660. https ://doi.org/10.1007/s12665-018-7777-8

Santos I, Sousa L, Lourenço J (2018) Granite resource evaluation: example of an extraction area in the north of Portugal. Environ Earth Sci 77:608. https://doi.org/10.1007/s12665-018-7780-0

Sassoni E, Andreotti S, Scherer GW et al (2018) Bowing of marble slabs: can the phenomenon be arrested and prevented by inorganic treatments? Environ Earth Sci 77:387. https://doi. org/10.1007/s12665-018-7547-7

Siedel H (2018) Salt efflorescence as indicator for sources of damaging salts on historic buildings and monuments: a statistical approach. Environ Earth Sci 77:572. https://doi.org/10.1007/ s12665-018-7752-4

Siegesmund S, Sousa L, Knell C (2018) Thermal expansion of granitoids. Environ Earth Sci 77:41. https://doi.org/10.1007/s1266 5-017-7119-2 
Sousa L, Siegesmund S, Wedekind W (2018) Salt weathering in granitoids: an overview on the controlling factors. Environ Earth Sci 77:502. https://doi.org/10.1007/s12665-018-7669-y

Stück HL, Platz T, Müller A et al (2018) Natural stones of the SaaleUnstrut Region (Germany): petrography and weathering phenomena. Environ Earth Sci 77:300. https://doi.org/10.1007/s1266 5-018-7476-5

Tiennot M, Mertz JD, Bourgès A (2018) Sensitivity of kersantite toughness to moisture: influence of the phyllosilicates. Environ Earth Sci 77:483. https://doi.org/10.1007/s12665-018-7666-1

Vazquez P, Sánchez-Delgado N, Carrizo L et al (2018) Statistical approach of the influence of petrography in mechanical properties and durability of granitic stone. Environ Earth Sci 77:287. https:// doi.org/10.1007/s12665-018-7475-6

Vereshchagin OS, Frank-Kamenetskaya OV, Shumilova KV et al (2018) Carbonate sediments on decorative fountains in Peterhof, Russia. Environ Earth Sci 77:56. https://doi.org/10.1007/s1266 5-018-7243-7

Wedekind W, Gross C, Hoffmann A et al (2018) Damage phenomenon and petrophysical properties of sandstones at the Phnom Bakheng Temple (Angkor, Cambodia): First investigations and possible conservation measures. Environ Earth Sci. https://doi. org/10.1007/s12665-018-7915-3 